\title{
A Case of Magnesium Deficiency Associated with Insufficient Parathyroid Hormone Action and Severe Osteoporosis
}

\author{
IPPEI KANAZAWA, MASAHIRO YAMAMOTO, TORU YAMAGUCHI, MIKA YAMAUCHI, SHOZO YANO \\ AND TOSHITSUGU SUGIMOTO
}

Department of Internal Medicine 1, Shimane University Faculty of Medicine, Shimane 693-8501, Japan

\begin{abstract}
The relationship between osteoporosis and magnesium $(\mathrm{Mg})$ deficiency is still controversial. Here we report a case of an 82-year-old woman with a giant adenomatous goiter and severe osteoporosis with multiple vertebral fractures, whose clinical course indicated that her osteoporosis was probably due to $\mathrm{Mg}$ deficiency. She visited our hospital for treatments of tetany. Laboratory data showed the existence of hypomagnesemia, hypocalcemia, hypokalemia, vitamin D deficiency, and slightly elevated intact PTH. Intravenous administration of $\mathrm{Mg}$ not only improved these electrolyte abnormalities but also increased serum levels of intact PTH, bone formation markers, 1,25-dihydroxyvitamin D, as well as bone resorption markers in the urine, and lowered urinary phosphate reabsorption. Hypomagnesemia on admission seemed to arise from long-lasting poor food intake and malnutrition, because it improved after the disappearance of dysphagia with a goiter resection. After the operation, BMD values at the lumbar spine and femoral neck obviously increased during 6 months of $\mathrm{Mg}$ supplementation without any specific therapies for osteoporosis. $\mathrm{Mg}$ deficiency in this case seemed to cause impaired secretion of PTH from the parathyroid and the refractoriness of bone and kidney to the hormone, which led to the suppression of both bone remodeling and renal vitamin D production. These processes were probably linked to her severe osteoporosis, which was reversed by Mg supplementation.
\end{abstract}

Key words: Magnesium, Hypomagnesemia, Osteoporosis, Parathyroid hormone, Adenomatous goiter

(Endocrine Journal 54: 935-940, 2007)

SERUM calcium levels are normally regulated within a relatively narrow range by the parathyroid gland through a negative feedback mechanism: Increased secretion of parathyroid hormone (PTH) by a fall in blood calcium levels enhances the mobilization of calcium, mainly by bone resorption, and then calcium levels are rapidly restored. Chronic magnesium $(\mathrm{Mg})$ deficiency would result in hypocalcemia $[1,2]$, because of the impairment of PTH secretion [3-7] and/ or resistance of target organ to PTH action $[4,6,8]$. Previous studies have demonstrated that serum PTH concentration was suppressed in patients with hypomagnesemia [4, 5], and $\mathrm{Mg}$ substitution therapy enhanced PTH secretion and reversed PTH target-organ

Received: March 9, 2007

Accepted: October 23, 2007

Correspondence to: Ippei KANAZAWA M.D., Department of Internal Medicine 1, Shimane University Faculty of Medicine, 89-1 Enya-cho, Izumo 693-8501, Japan resistance, and thus serum calcium concentration returned to normal within several days $[4,7]$. In addition, $\mathrm{Mg}$ deficiency could inhibit the synthesis of 1,25-dihydroxy vitamin $\mathrm{D}\left(1,25(\mathrm{OH})_{2} \mathrm{D}\right)$ [9-11] as well as its action on bone [11]. Accumulating data have shown that a long-term Mg deficiency and resulting hypomagnesemia could cause osteoporosis and bone fractures through these dysfunctions of PTH and vitamin D action [12, 13-19]. However, other studies have shown no relationship between $\mathrm{Mg}$ deficiency and osteoporosis [20-22], and it still seems to be controversial whether or not $\mathrm{Mg}$ deficiency could cause osteoporosis. Here we report a patient with a giant adenomatous goiter and severe osteoporosis exhibiting hypomagnesemic hypocalcemia, whose osteoporosis was reversed by $\mathrm{Mg}$ supplementation with chronological improvements in bone mineral density (BMD), serum calcium, PTH, bone metabolic markers, and $1,25(\mathrm{OH})_{2} \mathrm{D}$. These findings suggest that osteoporosis in this case was probably linked to $\mathrm{Mg}$ deficiency. 


\section{Case Report}

The patient was an 82-year-old Japanese woman. She was pointed out with a goiter in 1980 . The goiter enlarged gradually and caused dysphagia and poor food intake. She was referred to Shimane University Hospital in 2005 because of tetany. She had no history of smoking, drinking, or abnormal menopause.

On admission, physical findings revealed body height, $130 \mathrm{~cm}$; body weight, $30 \mathrm{~kg}$; blood pressure, 128/82 mmHg; pulse rate, 80 beats $/ \mathrm{min}$; and body temperature, $37.2^{\circ} \mathrm{C}$. She presented an extremely giant thyroid tumor that was $10 \times 6 \mathrm{~cm}$ in diameter. Lymph nodes were not palpable. There were no abnormal findings in lung, heart or abdomen. No edema was found in pretibia or foot. Neurological examination showed that patella tendon reflex and Achilles tendon reflex were attenuated. Trousseau and Chvostek signs were positive, suggesting the complication of tetany.

Laboratory data on admission are shown in Table 1. There were hypomagnesemia, hypocalcemia and hypokalemia with serum magnesium $(\mathrm{Mg}) 1.1 \mathrm{mg} / \mathrm{dl}$, serum calcium (corrected by serum albumin) (cCa) $7.6 \mathrm{mg} / \mathrm{dl}$, and serum potassium $(\mathrm{K}) 2.2 \mathrm{mEq} / \mathrm{l}$. Fractional excretions of these minerals, however, were not suppressed. There was vitamin D deficiency or insufficiency with serum $25(\mathrm{OH}) \mathrm{D} 5.6 \mathrm{ng} / \mathrm{ml}$ and slightly elevated serum intact PTH $(88.8 \mathrm{pg} / \mathrm{ml})$. Low FT3 was noticed, but TSH and FT4 levels were normal. Lumbar spine X-ray indicated several vertebral compression fractures (Th11,12, and L1-4), and dual-energy X-ray absorptiometry revealed severe osteoporosis with lumbar BMD $0.328 \mathrm{~g} / \mathrm{cm}^{2}$ (T-score; -6.16 SD) and femoral neck BMD $0.179 \mathrm{~g} / \mathrm{cm}^{2}$ (T-score; -5.57 SD).

$\mathrm{Mg}$ tolerance test [23] was performed to examine whether or not hypocalcemia and hypokalemia were secondarily caused by hypomagnesemia. After $\mathrm{Mg}$ tolerance test by intravenous $\mathrm{Mg}$ administration (720 $\mathrm{mg} / 12 \mathrm{hr}$ ), serum intact PTH level was markedly elevated to $328 \mathrm{pg} / \mathrm{ml}$ and serum levels of $\mathrm{cCa}$ and $\mathrm{K}$ were simultaneously improved (Fig. 1), showing that hypocalcemia, hypokalemia, and relative hypoparathyroidism were due to hypomagnesemia. In order to examine whether or not there was refractoriness of bone and kidney to PTH under hypomagnesemia, we followed chronological changes in serum bone formation markers [bone-specific alkaline phosphatase (BAP) and osteocalcin (OC)] and urinary bone resorption markers [type I collagen cross-linked N-telopeptide (UNTX)
Table 1. Laboratory data on admission

\begin{tabular}{|c|c|}
\hline \multicolumn{2}{|l|}{ Biochemistry } \\
\hline $\mathrm{TP}$ & $5.1 \mathrm{~g} / \mathrm{dl}$ \\
\hline Alb & $2.2 \mathrm{~g} / \mathrm{dl}$ \\
\hline AST & $30 \mathrm{IU} / 1$ \\
\hline ALT & $20 \mathrm{IU} / 1$ \\
\hline ALP & $257 \mathrm{IU} / 1$ \\
\hline BUN & $20.7 \mathrm{mg} / \mathrm{dl}$ \\
\hline Crea & $1.33 \mathrm{mg} / \mathrm{dl}$ \\
\hline $\mathrm{Na}$ & $140 \mathrm{mEq} / \mathrm{l}$ \\
\hline $\mathrm{K}$ & $2.2 \mathrm{mEq} / 1$ \\
\hline $\mathrm{Cl}$ & $96 \mathrm{mEq} / 1$ \\
\hline $\mathrm{cCa}$ & $7.6 \mathrm{mg} / \mathrm{dl}$ \\
\hline $\mathrm{Ca}^{2+}$ & $1.98 \mathrm{mEq} / \mathrm{l}$ \\
\hline $\mathrm{P}$ & $1.8 \mathrm{mg} / \mathrm{dl}$ \\
\hline $\mathrm{Mg}$ & $1.1 \mathrm{mg} / \mathrm{dl}$ \\
\hline \multicolumn{2}{|l|}{ Urinary biochemistry } \\
\hline $24 \mathrm{hCcr}$ & $23 \mathrm{ml} / \mathrm{min}$ \\
\hline $\mathrm{K}$ & $31 \mathrm{mEq} /$ day \\
\hline $\mathrm{Ca}$ & $28.8 \mathrm{mg} /$ day \\
\hline$\% \mathrm{TRP}$ & $96 \%$ \\
\hline $\mathrm{Mg}$ & $15.3 \mathrm{mg} /$ day \\
\hline $\mathrm{Fe}_{\mathrm{Mg}}$ & $4.65 \%$ \\
\hline \multicolumn{2}{|l|}{$\mathrm{Mg}$ tolerance test } \\
\hline Urine $\mathrm{Mg}$ excretion rate & $2.07 \%$ \\
\hline \multicolumn{2}{|l|}{ Bone metabolic marker } \\
\hline BAP & $21.8 \mathrm{U} / 1$ \\
\hline $\mathrm{OC}$ & $2.1 \mathrm{ng} / \mathrm{ml}$ \\
\hline uNTX & $45.0 \mathrm{nMBCE} / \mathrm{mMCr}$ \\
\hline DPD & $9.1 \mathrm{nM} / \mathrm{mMCr}$ \\
\hline \multicolumn{2}{|l|}{ Endocrinology } \\
\hline Intact PTH & $88.8 \mathrm{pg} / \mathrm{ml}$ \\
\hline PTHrp & $<1.1 \mathrm{pmol} / 1$ \\
\hline $25(\mathrm{OH}) \mathrm{D}$ & $5.6 \mathrm{ng} / \mathrm{ml}$ \\
\hline $1.25(\mathrm{OH})_{2} \mathrm{D}$ & $10.0 \mathrm{pg} / \mathrm{ml}$ \\
\hline Calcitonin & $39.8 \mathrm{pg} / \mathrm{ml}$ \\
\hline $\mathrm{TSH}$ & $2.92 \mu \mathrm{U} / \mathrm{ml}$ \\
\hline $\mathrm{FT}_{3}$ & $1.0 \mathrm{ng} / \mathrm{dl}$ \\
\hline $\mathrm{FT}_{4}$ & $1.4 \mathrm{ng} / \mathrm{dl}$ \\
\hline Thyroglobulin & $610 \mathrm{ng} / \mathrm{ml}$ \\
\hline anti-TPO Ab & $<0.3 \mathrm{U} / \mathrm{ml}$ \\
\hline anti-TG Ab & $<0.3 \mathrm{U} / \mathrm{ml}$ \\
\hline TBII & $5.2 \%$ \\
\hline $\mathrm{TsAb}$ & $129 \%$ \\
\hline
\end{tabular}

cCa: serum calcium concentration corrected with serum albumin level; \%TRP: tubular reabsorption of phosphate; FeMg: fractional excretion of Mg; BAP: bone alkalinphosphatase; OC: osteocalcin; uNTX: urinary type I collagen cross-linked N-telopeptide; DPD: Deoxypyridinolin; 25(OH)D: 25-hydroxyvitamin $\mathrm{D} ; 1.25(\mathrm{OH})_{2} \mathrm{D}$ : 1.25-dihydroxyvitamin D; anti-TPO Ab: anti-thyroid peroxidase antibody; anti-TG Ab: anti-thyroglobulin antibody; TBII: TSH binding inhibitory immunoglobulin; TsAb: thyroid stimulating antibody

*Normal range: $\mathrm{Mg}$ tolerance test: $>70 \%$; intact PTH: $11-54 \mathrm{pg} /$ $\mathrm{ml}$; PTHrp: <1.1 pmol/1; 25(OH)D: 7.6-29.1 ng/ml; $1.25(\mathrm{OH}) \mathrm{D}$ : 27.5-68.7 pg/ml; BAP: 13.0-33.9 U/l; OC: $2.5-13.0 \mathrm{ng} / \mathrm{ml}$; uNTX: <40 nMBCE/mM-Cr; DPD: $2.8-7.6 \mathrm{nM} / \mathrm{mMCr}$. 


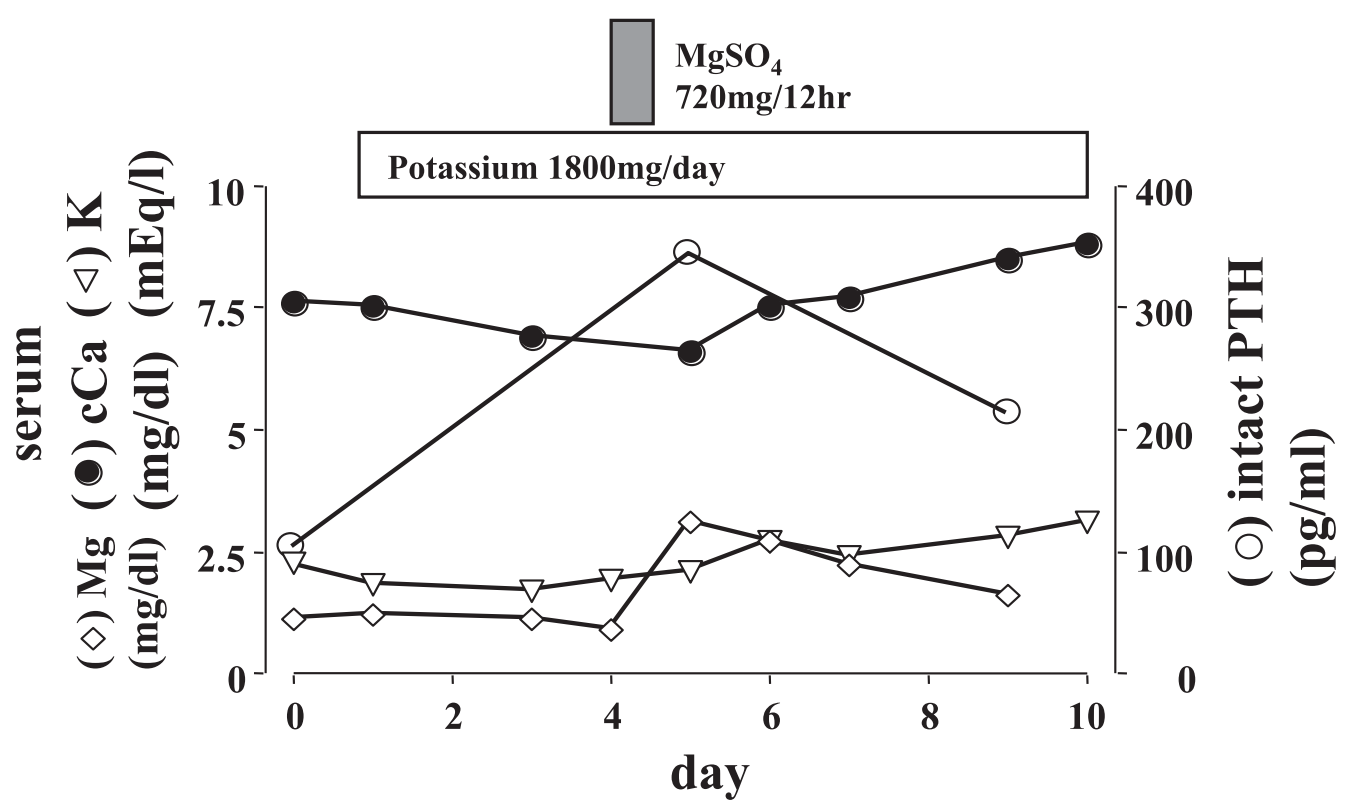

Fig. 1. Chronological changes in intact $\mathrm{PTH}, \mathrm{cCa}$, and $\mathrm{K}$ after $\mathrm{Mg}$ administration

Intact PTH level was markedly elevated and serum levels of $\mathrm{cCa}$ and $\mathrm{K}$ were improved spontaneously and simultaneously after intravenous $\mathrm{Mg}$ administration $(720 \mathrm{mg} / 12 \mathrm{hr})$.

and deoxypyridinoline (uDPD)], as well as tubular reabsorption of phosphate (\%TRP), and serum $1,25(\mathrm{OH})_{2} \mathrm{D}$. When $\mathrm{Mg}$ was administered, we observed an temporal and prompt increase in serum intact PTH with concomitant decrease in \%TRP and increase in $1,25(\mathrm{OH})_{2} \mathrm{D}$. Both bone formation and resorption markers were also increased. These results suggest that bone turnover and PTH resistance in bone and kidney were associated with Mg deficiency. These findings indicated that $\mathrm{Mg}$ was essential for PTH secretion from the parathyroid as well as PTH actions on the target organs, bone and kidney. Tetany also disappeared by Mg supplementation.

After normalization of $\mathrm{Mg}$ level under parenteral nutrition, the patient underwent the resection of thyroid tumor in the right lobe, and noticed the disappearance of dysphagia and the recovery of food intake. The resected specimen showed that the thyroid gland epithelium consisting of rich eosinophilic granular cells was arranged in cords and follicles. These cells did not have polymorphism and atypism and did not invade into blood vessels, suggesting that these finding were compatible with an adenomatous goiter. Her general condition improved after the operation, and serum levels of $\mathrm{Mg}$ and other minerals remained normal without any supplementation. Her postoperative thyroid function maintained normal by administration of levothy- roxine. On six months with no supplement of $\mathrm{Mg}$ after the operation, her body weight was increased to $31 \mathrm{~kg}$. BMD values at the lumbar spine and femoral neck were obviously increased to $0.383 \mathrm{~g} / \mathrm{cm}^{2}$ (T-score; -5.66 $\mathrm{SD})$ and $0.212 \mathrm{~g} / \mathrm{cm}^{2}$ (T-score; -5.28 SD) with no specific medication for osteoporosis, respectively.

\section{Discussion}

The association between hypomagnesemia and hypocalcemia has been reported by several investigators. Impaired secretion of PTH caused by reduction in serum $\mathrm{Mg}$ levels has been thought to be one of the major mechanisms by which hypocalcemia develops in $\mathrm{Mg}$ deficiency [3-7]. PTH secretion is known to be affected by extracellular $\mathrm{Mg}$ in vitro [24] and in vivo [25, 26]. Quitterer et al. have revealed that PTH secretion was blocked independently of the extracellular $\mathrm{Ca}^{2+}$ concentration in primary human parathyroid cells, when Mg was decreased [27]. They suggested that the paradoxical block of PTH release under Mg deficiency was mediated through a novel mechanism involving an increase in the activity of $\mathrm{G} \alpha$ subunits of heterotrimeric G-proteins [27], which is a key molecule in Ca-bone metabolism [28]. In our patient, intact PTH level was markedly increased by $\mathrm{Mg}$ adminstration, although it 

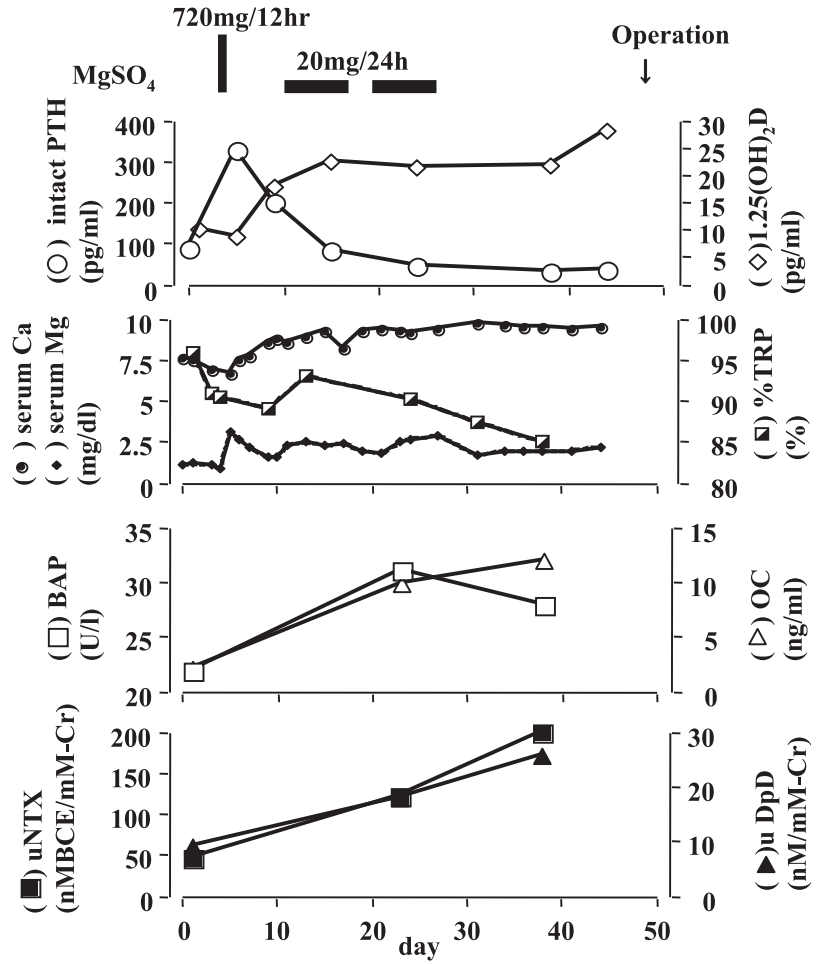

Fig. 2. Chronological changes in bone markers, \%TRP, and serum $1,25(\mathrm{OH})_{2} \mathrm{D}$ after $\mathrm{Mg}$ administration

Bone metabolic markers (BAP, OC, uNTX, and DPD) were obviously raised, \%TRP decreased and serum $1,25(\mathrm{OH})_{2} \mathrm{D}$ level increased. These findings suggest that $\mathrm{Mg}$ adminstration improved the refractoriness of bone and kidney to PTH.

was already slightly high on admission. This observation suggested that her PTH secretion on admission was not sufficient enough to counteract hypocalcemia.

Another mechanism by which hypocalcemia develops in Mg deficiency is through the resistance of PTH actions on target organs such as bone [29] and kidney [29-31]. In our case, bone metabolic markers and $1,25(\mathrm{OH})_{2} \mathrm{D}$ were not elevated and $\% \mathrm{TRP}$ was not suppressed despite the high value of intact PTH on admission, suggesting that bone and kidney were refractory to PTH action. Moreover, bone metabolic markers apparently increased and \%TRP decreased after the intravenous supplementation of $\mathrm{Mg}$, showing that the administration of Mg improved not only PTH secretion from the parathyroid but also the refractoriness of bone and kidney to PTH.

Serum phosphate in this case was very low on admission despite the high normal level of \%TRP. Mg deficiency is often caused by malnutrition, such as chronic alcoholism $[1,8,31,32]$ and gastrointentinal disorders [1, 33, 34], which might also cause hypophosphatemia in our patient. Indeed, the complication of low T3 syndrome and vitamin D deficiency or insufficiency suggests the existence of malnutrition in this case. In addition, vitamin D deficiency or insufficiency might aggravate hypophosphatemia further.

$\mathrm{Mg}$ depletion is thought to impair vitamin D metabolism, because serum $1,25(\mathrm{OH})_{2} \mathrm{D}$ concentrations are frequently low in patients with $\mathrm{Mg}$ deficiency [35], and $\mathrm{Mg}$ administration ameliorates the level of $1,25(\mathrm{OH})_{2} \mathrm{D}$ in Mg-deficient patients [7]. It has been reported that the synthesis of $1,25(\mathrm{OH})_{2} \mathrm{D}$ required a free intracellular magnesium concentration in vitro [36], and that $\mathrm{Mg}$ deficiency decreased the synthesis of $1,25(\mathrm{OH})_{2} \mathrm{D}$ in kidney. $\mathrm{Mg}$ deficiency also inhibits the binding of PTH to bone tissue in vivo [11]. Thus, hypomagnesemia could deteriorate hypocalcemia via the impairments of vitamin D metabolism and PTH action. The clinical observation in our patient seems to accord well with this pathogenesis.

$\mathrm{Mg}$ content in bone, which is a storehouse of $\mathrm{Mg}$, is thought to decrease under a condition of long-term $\mathrm{Mg}$ deficiency, thereby leading to impaired bone metabolism [13]. In addition, previous reports have shown that bone quality deteriorates under a low $\mathrm{Mg}$ condition $[14,15]$, and that subjects at low serum Mg levels are at risk for bone fractures [12]. It has been reported that dietary $\mathrm{Mg}$ supplementation affected bone metabolism and dynamic strength of bone in ovariectomized rats [16]. Family members affected with primary hypomagnesemia due to renal $\mathrm{Mg}$ wasting inherited in an autosomal dominant manner have been reported to demonstrate significant reductions in serum and lymphocyte $\mathrm{Mg}$ concentrations as well as decreased BMD values at the lumbar spine and proximal femur [17]. Taken together, these findings suggest that $\mathrm{Mg}$ deficiency might also act as a risk factor for osteoporosis $[18,19]$. However, other studies have failed to find the association between $\mathrm{Mg}$ deficiency and osteoporosis [20-22], and there are still controversies about this issue. In this case, $\mathrm{Mg}$ supplementation elevated bone turnover, which helped her BMD increase, and increased in $1,25(\mathrm{OH})_{2} \mathrm{D}$ level with relieving PTH resistance in bone and kidney.

Hypomagnesemia is known to arise from various disorders. Inadequate intake of $\mathrm{Mg}$ is one of gastrointestinal causes for hypomagnesemia. Our patient suffered from dysphagia because of her extremely giant thyroid tumor. Her nutritional status was improved 
and serum $\mathrm{Mg}$ levels returned to normal after the resection of thyroid tumor with modest oral supplementation of Mg. Thus, we suspected that poor food intake persisting until the operation might have caused $\mathrm{Mg}$ deficiency and hypomagnesemia in this case. Not only $\mathrm{Mg}$ deficiency but also improvement in nutritional conditions by increased food intake after the operation seemed to contribute to her BMD increase. Elevations in serum IGF-I and 25(OH)D levels may participate in this process, although these hormone levels were not measured again after the operation.

In conclusion, we presented a case of magnesium deficiency associated with insufficient parathyroid hormone action and severe osteoporosis. Severe osteoporosis might be caused by suppressed bone turnover and impaired activation of vitamin $\mathrm{D}$ due to the refractoriness of bone and kidney to $\mathrm{PTH}$, as well as poor nutritional status caused by reduced food intake due to dysphagia related to the giant thyroid tumor.

\section{References}

1. Wacker WE, Parisi AF (1968) Magnesium metabolism. N Engl J Med 278: 712-717.

2. Rude RK, Singer FR (1981) Magnesium deficiency and excess. Ann Rev Med 32: 245-259.

3. Rude RK, Oldham SB, Sharp CF Jr, Singer FR (1978) Parathyroid hormone secretion in magnesium deficiency. J Clin Endocrinol Metab 47: 800-806.

4. Rude RK, Oldham SB, Singer FR (1976) Functional hypoparathyroidism and parathyroid hormone endorgan resistance in human magnesium deficiency. Clin Endocrinol (Oxf) 5: 209-224.

5. Anast CS, Winnacker JL, Forte LR Burns TW (1976) Impaired release of parathyroid hormone in magnesium deficiency. J Clin Endocrinol Metab 42: 707-717.

6. Allgrove J, Adami S, Fraher L, Reuben A, O'Riordan JL (1984) Hypomagnesemia: studies of parathyroid hormone secretion and function. Clin Endocrinol (Oxf) 21: 435-449.

7. Fuss M, Cogan E, Gillet C, Karmali R, Geurts J, Bergans A, Brauman H, Bouillon R, Corvilain J (1985) Magnesium administration reverses the hypocalcemia secondary to hypomagnesemia despite low circulating levels of 25-hydroxyvitamin D and 1,25-dihydroxy vitamin D. Clin Endocrinol (Oxf) 22: 807-815.

8. Estep H, Shaw WA, Watlington C, Hobe R, Holland W, Tucker SG (1969) Hypocalcemia due to hypomagnesemia and reversible parathyroid hormone unresponsiveness. J Clin Endocrinol Metab 29: 842-848.

9. Risco F, Climent P, Traba ML (1989) Vitamin D deficiency prevents the observation of a decrease in the synthesis of $1,25(\mathrm{OH})_{2} \mathrm{D}_{3}$ in magnesium-deficient rats. Med Sci Res 17: 279-280.

10. Lemay J, Gascon-Barre M (1992) Responsiveness of the intestinal 1,25-dihydroxyvitamin $D_{3}$ receptor to magnesium depletion in the rat. Endocrinology 130: 2767-2777.

11. Risco F, Traba ML, de la Piedra C (1995) Possible alterations of the in vivo $1,25(\mathrm{OH})_{2} \mathrm{D}_{3}$ synthesis and its tissue distribution in magnesium-deficient rats. Magnes
Res 8: 27-35.

12. Saito N, Tabata N, Saito S, Andou Y, Onaga Y, Iwamitsu A, Sakamoto M, Hori T, Sayama H, Kawakita $\mathrm{T}$ (2004) Bone mineral density, serum albumin and serum magnesium. J Am Coll Nutr 23: 701S-703S.

13. Sojka JE, Weaver CM (1995) Magnesium supplementation and osteoporosis. Nutr Rev 53: 71-74.

14. Kobayashi M, Hara K, Akiyama Y (2004) Effects of vitamin K2 (metatetorenone) and alendronate on bone mineral density and bone strength in rats fed a lowmagnesium diet. Bone 35: 1136-1143.

15. Bigi A, Foresti E, Gregorini R, Ripamonti A, Roveri N, Shah JS (1992) The role of magnesium on the structure of biological apatites. Calcif Tissue Int 50: 439-444.

16. Toba Y, Kajita Y, Masuyama R, Takada Y, Suzuki K, Aoe S (2000) Dietary magnesium supplementation affects bone metabolism and dynamic strength of bone in ovariectomized rats. J Nutr 130: 216-220.

17. Kantorovich V, Adams JS, Gaines JE, Guo X, Pandian MR, Cohn DH, Rude RK (2002) Genetic heterogeneity in familial renal magnesium wasting. J Clin Endocrinol Metab 87: 612-617.

18. Rude RK (1995) Magnesium deficiency: a heterogeneous cause of disease in humans. $J$ Bone Miner Res 13: 749-758.

19. Rude RK, Gruber HE (2004) Magnesium deficiency and osteoporosis: animal and human observations. $J$ Nutr Bioch 15: 710-716.

20. Freudenheim JL, Johnson NE, Smith EL (1986) Relationships between usual nutrient intake and bone-mineral content of women 35-65 years of age: longitudinal and cross-sectional analysis. Am J Clin Nutr 44: 863876 .

21. Angus RM, Sambrook PN, Pocock NA, Eisman JA (1988) Dietary intake and bone mineral density. Bone Miner 4: 265-277.

22. Michaelsson K, Holmberg L, Mallmin H, Wolk A, Bergstrom R, Ljunghall S (1995) Diet, bone mass, and osteoporosis Study. Eur J Nutr 40: 231-237. 
23. Rude RK (1993) Magnesium metabolism and deficiency. Endocrinol Metab Clin North Am 22: 377-395.

24. Sherwood LM, Herman I, Bassett CA (1970) Parathyroid hormone secretion in vitro: Regulation by calcium and magnesium ions. Nature 225: 1056-1058.

25. Buckle RM, Care AD, Cooper CW, Gitelman HJ (1968) The influence of plasma magnesium concentration on parathyroid hormone secretion. $J$ Endocrinol 42: 529-534.

26. Cholst IN, Steinberg SF, Tropper PJ, Fox HE, Segre GV, Bilezikian JP (1984) The influence of hypermagnesemia on serum calcium and parathyroid hormone levels in human subjects. $N$ Engl J Med 310: 1221-1225.

27. Quitterer U, Hoffmann M, Freichel M, Lohse MJ (2001) Paradoxical block of parathormone secretion is mediated by increased activity of G $\alpha$ subunits. J Biol Chem 276: 6763-6769.

28. Sargin H, Gozu H, Bircan R, Sargin M, Avsar M, Ekinci G, Yayla A, Gulec I, Bozbuga M, Cirakoglu B, Tanakol R (2006) A case of McCune-Albright syndrome associated with Gs alpha mutation in the bone tissue. Endocrine J 53: 35-44.

29. Levi J, Massry SG, Coburn JW, Llach F, Kleeman CR (1974) Hypocalcemia in magnesium-depleted dogs: Evidence for reduced responsiveness to parathyroid hormone and relative failure of parathyroid gland function. Metabolism 23: 323-335.

30. Chase LR, Slatopolsky E (1974) Secretion and metabolic efficacy of parathyroid hormone in patients with severe hypomagnesemia. J Clin Endocrinol Metab 38: 363-371.

31. Medalle R, Waterhouse C (1973) A magnesiumdeficient patient presenting with hypocalcemia and hyperphosphatemia. Ann Intern Med 79: 76-79.

32. Fankushen D, Raskin D, Dimich A, Wallach S (1964) The significance of hypomagnesemia in alcoholic patients. Am J Med 37: 802-812.

33. Hanna S, Harrison M, MacIntyre I, Fraser R (1960) Syndrome of magnesium deficiency in man. Lancet 2: 172-175.

34. Booth CC, Babouris N, Hanna S, MacIntyre I (1963) Incidence of hypomagnesaemia in intestinal malaborption. Brit MJ 2: 141-144.

35. Rude RK, Adams JS, Ryzen E, Endres DB, Niimi H, Horst RL, Haddad JG Jr, Singer FR (1985) Low serum concentrations of 1,25-dihydroxyvitamin D in human magnesium deficiency. J Clin Endocrinol Metab 61: 933-940.

36. Risco F, Traba ML (1992) Influence of magnesium on the in vitro synthesis of 24,25-dihydroxyvitamin $\mathrm{D}_{3}$ and 1,25-dihydroxyvitamin $\mathrm{D}_{3}$. Magnes Res 5: 5-14. 